\title{
VASH1 wt Allele
}

National Cancer Institute

\section{Source}

National Cancer Institute. VASH1 wt Allele. NCI Thesaurus. Code C92494.

Human VASH 1 wild-type allele is located in the vicinity of $14 \mathrm{q} 24.3$ and is approximately 21

$\mathrm{kb}$ in length. This allele, which encodes vasohibin-1 protein, plays a role in the regulation

of the proliferation and migration of endothelial cells and vascular branch formation. 